\title{
Financial Factors and Non-Financial to Financial Distress Insurance Companies That Listed in Indonesia Stock Exchange
}

\author{
Liahmad $^{1}$, Kartika Rusnindita ${ }^{2}$, Yuni Putri Utami ${ }^{3}$, Saleh Sitompul ${ }^{4}$ \\ 1,2,3 Universitas Bahaudin Mudhary Madura, Indonesia \\ ${ }^{4}$ STIE ITMI Medan, Sumatera Utara, Indonesia \\ liahmad@unibamadura.ac.id, kartika.rusnindita@gmail.com,yuni.p.utami@gmail.com
}

\begin{abstract}
This study aims to test the influence of financial factors in the form of liquidity, cash flow, company size, institutional ownership, earnings and the factors of non-financial form of the independent commissioner against the financial distress of insurance companies that listed in Indonesia stock Exchange. The population of this research as many as 17 of the insurance company. The sampling technique using purposive sampling method, so that the obtained 15 sample company for 4 years of observations of the years 2017 - 2020, with 60 observations of the study. Data analysis using descriptive statistical analysis and logistic regression analysis. The results show that liquidity, cash flows, institutional ownership and independent commissioner does not affect significantly to financial distress, while the method of the size of the company and profit and significant effect on financial distress.
\end{abstract}

Keywords

financial factor, factor nonfinancial; financial distress

\section{Introduction}

The financial issue is a common phenomenon that can happen in a company. The financial problems that occur continuously can bring the company to a more serious condition that is financial distress. Platt and Platt (2002) defines financial distress as the stages of deterioration in the financial condition experienced by a company that occurred prior to the occurrence of bankruptcy or liquidation. If this is the case, then management is not able to monitor the financial condition of the company, which will result in increased business risk. Financial distress is usually started from the liquidity pressures that increasingly heavy, then continues on the condition of the declining assets which resulted in the company is not able to pay its financial obligations so as to bring the company towards bankruptcy.

Financial distress is usually caused due to the presence of a series of errors that occur in the company, decision-making by managers, and the weaknesses that relate directly or indirectly to the management (Brigham and Daves, 2004). Internally, the financial distress of the company occurs due to several factors including the amount of the debt, operational losses and the difficulty of cash flows. Internal factors also is a factor in the occurrence of financial distress is the strategy of the company. Porter (1991) stating the reason of a company's success or failure is caused by the strategy set of the company. Not only because of internal factors, financial distress can also occur due to external factors, i.e. the factors outside the company that are macro-economic influence either directly or indirectly to the financial distress of the company. These factors can be in the form of financial factors and non-financial daopat form of a rise in the interest rate of the loan that is also associated with the internal problems of the company, namely liquidity. 
Liquidity is a major factor that's greatly affect the financial distress of the company. Liquidity is associated with the amount of debt the company because liquidity is the ability of a company to pay its liabilities-the financial obligations of that soon must be repaid (short-term). The liquidity ratio is the "Ratio used to determine the ability of the company to meet its short term obligations in a timely manner." When the company is in an unhealthy state can mean the company is in a position illiquid. A company that constantly be in the condition of the liquid will take the company to a more serious condition that is financial distress.

In addition to liquidity, profit is also one of the factors that affect the financial distress of the company. Profit is the difference between revenues and expenses. Mahasiswa memahami sifat dari Statement defines the accounting profit as the change in equity of an entity during one particular period resulting from transactions and events or events that comes not from the owner (Harahap, 2011). If income is greater than the load, then the company will get profit. Vice versa if the income is less than the cost the company will incur a loss. The company continues to experience losses will be vulnerable to financial problems. Financial conditions continue to deteriorate can end up in financial distress and bankruptcy. Research Elloumie and Gueyie (2001) categorize companies that experience financial distress is a company that is earning per share negative long-term.

A proper assessment of the achievements of a company should not only pay attention to the company's ability to generate profits but also pay attention to the company's ability to generate positive cash flow from its operations. The cash flow statement can help the wearer to see how the balance of cash and cash equivalents in the balance sheet of the company changed from the beginning to the end of the accounting period and what it means to such changes for the company, whether show the achievements of the positive or negative. If the statement of cash flows continuously demonstrate the achievements of the negative, it will have an impact on the financial condition of the company. The financial condition of the continuous decline can make the company experience financial distress. Research McCue (1991) defines companies that experience financial distress is a company with negative cash flow.

Asset restructuring and diversification is an effort that can be done by the company to resolve financial distress. Therefore, for a company that smart so no symptoms and the condition of financial distress will then quickly do the restructuring of the business that survived the bankruptcy. The efforts of restructuring will assets and diversify the business could not be done without the presence of the assets of the company are adequate. Therefore, the total assets is also one of the factors that affect the financial distress of the company. The size of the company describes how large the total assets owned by a company. According to Rajan and Zingales that the Size of a large company would be better in a diversified and tend to be smaller bankruptcy." The company's strategy is one of the factors of financial distress. One strategy of the company is implementation of Good Corporate Governance. Good Corporate Governance according to Chrisnanda (2018) is "An ordinance of the corporate governance becomes an important aspect in the operations of the company to achieve the goal of building a healthy company." Good Corporate Governance has four factors therein, namely: audit committee, the proportion of independent commissioners, institutional ownership, and managerial ownership (Solar and Yustivandana, 2018).

Institutional ownership is the ownership of the company shares owned by institutions such as insurance companies, banks, investment companies, and the ownership of other institutions." Ownership insititusional produce management that focus on the performance of the company because of the presence of institutional ownership, the manager will focus 
more attention on the performance of the company, so it can reduce the action of the managers of the company selfish. Bodroastuti (2019) stated institutional ownership an increasingly large will increase the utilization of the company's assets so that financial distress can be minimized.

Independent commissioner according to is the Commissioner who is not a member of the management, the majority shareholder, officer or in any other way that relates directly or indirectly with the majority shareholder of a company that oversees the management of the company." The independent commissioner is expected to oversee the management of the company as well. Good corporate governance will affect the financial condition of the company. Research conducted Nur (2017) states with increasing number of independent commissioners in a company, then the risk of the occurrence of financial distress will be smaller.

Financial distress itself can occur in a variety of companies, did not escape the insurance company. According to (Darmawi, 2014) "In view of the business, insurance is a company whose main businesses receive or sell services, transfer of risk from another party, and gained the advantage with a system for risk sharing (sharing of risk) among a large number of customers.

\section{Review of Literatures}

\subsection{Financial Distress}

Financial distress is a condition where a company is in financial difficulties and so can not provide funds for memenuhihutang smooth.

\subsection{Liquidity}

Liquidity is the ability of a company to pay its liabilities-the financial obligations of a company that soon must be repaid (which are short term). According to Afiezan et al (2020) a liquid company means that the company has large funds to pay all of its obligations. The more liquid the company is, the more internal funds it will have to meet its operational needs.

\subsection{Cash Flow}

Cash flow is a summary of the cash flow for a certain period, this report is sometimes called sources report the use of the company's operations, investment, and cash flow financing as well as shows the company's cash and marketable securities during the period.

\subsection{Size of the Company}

The size of the company assessed through assets owned by the company. The size of the company that large would be better in a diversified and tend to be smaller bankruptcy. The size of the company also directly reflect the high and low operating activities of a company.

\subsection{Institutional Ownership}

Institutional ownership is the Ownership of shares by the government, institutions, legal entities, financial institutions, and other institutions. Institutional ownership is the proportion of shares of common stock owned by the parties institutional. 


\subsection{Earnings}

Profit is the change in equity of an entity during one particular period resulting from transactions and events or events that are not coming from the owner.

\subsection{Independent Commissioner}

Independent commissioner is a "Member of the board of commissioners who are not affiliated with the management, the members of the board of commissioners and shareholders, as well as free from the business relationship or other relationships that may affect the ability to act independently or acting solely for the sake of the interests of the company.

\subsection{Conceptual Framework}

From a review of the literature that has been described above, it can be seen related variables in this study can be formulated through a framework of thought is as follows:

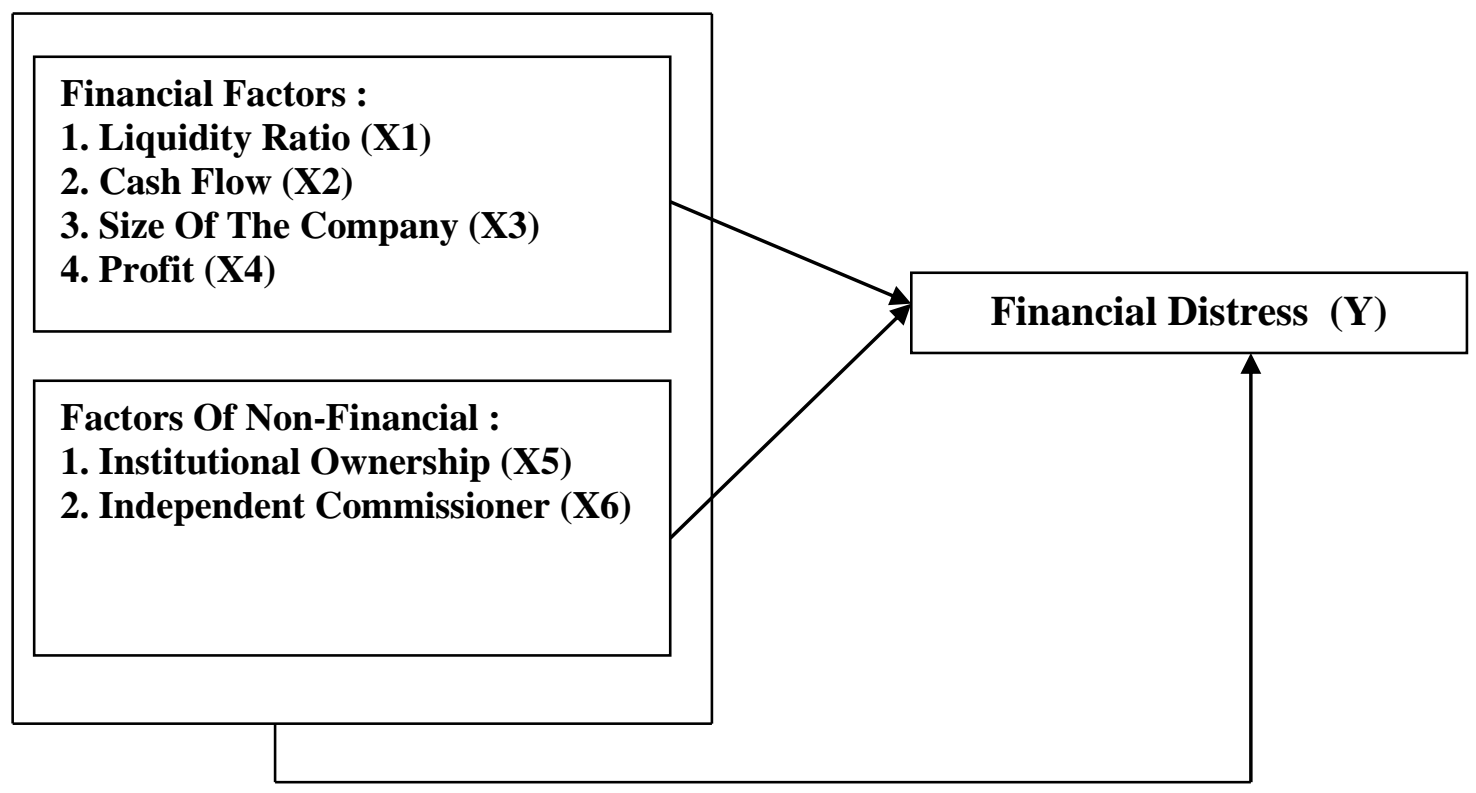

Figure 1. Conceptual Framework

\section{Research Methods}

This research is included quantitative research because the data used in the form of numbers. The Data used in this research is secondary. Secondary Data in penetilian this is the data of financial statements of insurance companies That listed in Indonesia stock Exchange. The population in this research is all the financial statements of insurance companies listed in Indonesia stock Exchange from year 2017-2020. The criteria for the population used is the annual financial statements of insurance companies on the IDX. As for the sample used in this study are the annual financial statements of insurance companies from the years 2017-2020. Sampling technique with purposive sampling technique used is the method of time series for 4 years from 2017-2020.

The type of data used in this research is secondary data. The secondary Data used is the data obtained based on the results of the publication by the Indonesia stock Exchange (BEI) is the annual report of the company, the history of the companies, journals, scientific literature, research earlier, the reports are published and the data obtained from the internet media. Data Collection method used in this research is the first Stage was conducted 
through a literature study of the collection of supporting data in the form of literature, previous research, and the reports published to get an overview of this research. The second stage is conducted through secondary data collection required the form of the reports published by the Indonesia stock Exchange (BEI) through www.idx.co.id.

\section{Discussion}

\subsection{The Effect of Liquidity on Financial Distress}

Based on the results of the study showed that the significance value of liquidity on the financial distress of of 0.117 where it is greater than the significance value of 0.05 and the value of the regression coefficient of 1,075 which means that the variables of liquidity and no significant positive effect on financial distress. This indicates liquidity does not affect the financial distress of companies registered insurance Indonesia stock Exchange Year 2017-2020. So regardless of the massive liquidity of the company will not affect the likelihood of firms experiencing financial distress. This research is in line with the research of the Princess and the Merkusiawati (2014) which states that liquidity has no effect on financial distress. But the research is at odds with research conducted Widhiyari and Merkusiawati (2015) which states that the liquidity significantly negative effect on financial distress.

\subsection{The Influence of Cash Flow on Financial Distress}

Based on the results of the study showed that the significance value of cash flows to financial distress by 0,259 where it is greater than the significance value of 0.05 and the value of the regression coefficient of 8,326 which means that the variable cash flow and no significant positive effect on financial distress. This indicates the cash flow does not affect the financial distress of companies registered insurance Indonesia stock Exchange Year 2017-2020. This research is in line with research Atmini (2015) which states that the cash flow has no significant effect on financial distress. But the research is at odds with research conducted Donker, et al (2009) which states that the cash flow significantly negative effect on financial distress.

\subsection{The Influence of the Size of the Company against Financial Distress}

Based on the results of the study showed that the value of the significance of the size of the company against the financial distress 0.011 where it is smaller than the significance value of 0.05 and the value of the regression coefficient of $-1,896$ which means that the variable size of the company and a significant negative effect on financial distress. This indicates the size of the company affect the financial distress of companies registered insurance Indonesia stock Exchange Year 2017-2020. This research is in line with research Shahwan (2015) which states that the size of the company and the negative effect it signifikasn against financial distress. But the research is at odds with research conducted Donker, et al (2009) which states that firm size does not affect the financial distress.

\subsection{The Influence of Institutional Ownership on Financial Distress}

Based on the results of the study showed that the significance value of institutional ownership on financial distress by 0,066 where it is greater than the significance value of 0.05 and the value of the regression coefficient of $-12,052$ which means that the variable institutional ownership and no significant negative effect on financial distress. This indicates institutional ownership does not affect the financial distress of companies registered insurance Indonesia stock Exchange Year 2017-2020. This research is in line 
with research Shahwan (2015) which states that institutional ownership has no effect on financial distress. But the research is at odds with research conducted Helena and Saifi (2018) which states that the ownership of institusional significantly negative effect on financial distress.

\subsection{The Influence of Income on Financial Distress}

Based on the results of the study showed that the significance value of profit to the financial distress of are 0.008, where it is smaller than the significance value of 0.05 and the value of the regression coefficient of $-114,0155$ which means that the variables of income and a significant negative effect on financial distress. This indicates earnings effect against the financial distress of companies registered insurance Bursa efek Indonesia (Year 2017-2020). This research is in line with research Atmini (2005) which states that the income effect is negative in signifikasn against financial distress. But the research is at odds with research conducted Darmawan and Supriyanto (2018) which states that income has no effect on financial distress.

\subsection{The Influence of the Independent Commissioner against Financial Distress}

Based on the results of the study showed that the significance value of the independent commissioner against financial distress by 0,633 where it is greater than the significance value of 0.05 and the value of the regression coefficient of $-2,367$ which means that the variables are independent commissioner and no significant negative effect on financial distress. This indicates the independent commissioner has no effect on financial distress of companies registered insurance Indonesia stock Exchange Year 20172020). This research is in line with the research of the Princess and the Merkusiawati (2014) which states that the independent commissioner has no effect on financial distress. But the research is at odds with research conducted Pramudena (2017) which states that the independent commissioner significantly positive effect on financial distress.

\subsection{Simultaneous Influence of Liquidity, Cash Flow, Company Size, Institutional} Ownership, Earnings and the Independent Commissioner against Financial Distress

Based on the results of the study showed that the significance value of liquidity, cash flow, company size, institutional ownership, earnings and the independent commissioner against the financial distress of 0.000 . The value is greater than the significance value of 0.05 , this shows that there is a simultaneous influence of liquidity, cash flow, company size, institutional ownership, earnings and the independent commissioner against financial distress.

\section{Conclusion}

Based on the results of the research can be summed up as follows:

1. Liquidity and no significant positive effect on financial distress. This is indicated by the regression coefficient of the liquidity of 1.075 and significance value of 0.117 , which is greater than 0.05 . It can be concluded that liquidity does not affect the financial distress of insurance companies that listed in Indonesia stock Exchange.

2. Cash flow and no significant positive effect on financial distress. This is indicated by the regression coefficient, the cash flow amounted to 8,326 and significance value 0,259 which is greater than 0.05 . It can be concluded that cash flow does not affect the financial distress of insurance companies that listed in Indonesia stock Exchange. 
3. The size of the company and a significant negative effect on financial distress. This is indicated by the coefficient of regression of the size of the company amounted to $-1,896$ and significance value 0,011 smaller than 0.05 . It can be concluded that the size of the company affect the financial distress of insurance companies that listed in Indonesia stock Exchange.

4. Institutional ownership and no significant negative effect on financial distress. This is indicated by the regression coefficient institutional ownership of $-12,052$ and significance value 0,066 smaller than 0.05 . It can be concluded that institutional ownership does not affect the financial distress of insurance companies that listed in Indonesia stock Exchange.

5. Profit and a significant negative effect on financial distress. This is indicated by the regression coefficient a profit of $-114,015$ and significance values are 0.008 which is less than 0.05. It can be concluded that the earnings effect against the financial distress of insurance companies that listed in Indonesia stock Exchange.

6. Independent commissioner and no significant negative effect on financial distress. This is indicated by the regression coefficient of the independent commissioner of $-2,367$ and significance value 0,633 which is greater than 0.05 . It can be concluded that the independent commissioner has no effect on financial distress of insurance companies that listed in Indonesia stock Exchange.

7. Liquidity, cash flow, size of the company, institutional ownership, earnings and the independent commissioner simultaneously have a significant effect on financial distress. This is indicated by a significance value of 0.000 is smaller than 0.05 . It can be concluded that the liquidity, cash flow, company size, institutional ownership, earnings and the independent commissioner simultaneously affect the financial distress of insurance companies that listed in Indonesia stock Exchange.

\section{References}

Afiezan, A., et al. (2020). The Effect of Free Cash Flow, Company Size, Profitability and Liquidity on Debt Policy for Manufacturing Companies Listed on IDX in 2016-2019 Periods. Budapest International Research and Critics Institute-Journal (BIRCIJournal). P. 4005-4018.

Chrisnanda, Daniella Okke. 2014. "Analisis Penerapan Good Corporate Governance pada Perusahaan Keluarga PT. Danliris di Surakarta, Jawa Tengah”. Agora Vol 2 No 2.

Darmawan, Arif dan Supriyanto, Joko. 2018. "The Effect of Financial Ratio on Financial Distress in Predicting Bankruptcy." Journal Of Applied Managerial Accounting, Vol. 2, No. 1. March, 2018Deviacita, Arieany Widya dan Achmad, Tarmizi. 2012. "Analisis

Ghozali, Imam. 2016. Aplikasi Analisis Multivariate dengan Program SPSS. Edisi Ke 4. Semarang: Badan Penerbit Universitas Diponegoro.

Harahap, Sofyan Syafri. 2011. Teori Akuntansi. Edisi Revisi 2011. Jakarta: Rajawali Pers. Helena, Savera dan Saifi, Muhammad. 2018. "Pengaruh Corporate governance Terhadap Financial Distress (Studi Pada Perusahaan Transportasi yang Terdaftar di Bursa Efek Indonesia Periode 2013-2016)". Jurnal Administrasi Bisnis (JAB), Vol. 60 No. 2 Juli 2018.

Kuncoro, Mudrajad. 2013. Metode Riset untuk Bisnis dan Ekonomi. Edisi 4. Jakarta: Erlangga.

Social Science, Education and Humanities Research (ASSEHR), volume 186. 
Frastuti, Melia dan Saleh Sitompul.2020. Reformasi Sistem Administrasi Pemerintahan, Penakhlukkan Di Darat Dan Dilautan Pada Era Bani Umayyah. Shar-E: Jurnal Kajian Ekonomi Hukum Syariah. Vol. 6 No. 2 Juli 2020, Hal. 119-127.

Nailufar, Fanny., Sufitrayati dan Badaruddin. 2018. "Pengaruh Laba dan Arus Kas Terhadap Kondisi Financial Distress Pada Perusahaan Non Bank Yang Terdaftar Di Bursa Efek Indonesia”. Jurnal Penelitian Ekonomi Akuntansi (JENSI), Vol. 2, Desember 2018.

Nurhudawi, Saleh Sitompul. 2020. Analisis Return Saham Pada Perusahaan Pertambangan Batubara Di Bursa Efek Indonesia. Shar-E: Jurnal Kajian Ekonomi Hukum Syariah. Vol. 6 No. 2 Juli 2020, Hal. 108-116.

Ichsan, R. et al. (2020). Determinant of Sharia Bank's Financial Performance during the Covid19 Pandemic. Budapest International Research and Critics Institute-Journal (BIRCIJournal). P. 298-309.

Rahayu, S. et al. (2020). Effect Of Work To Family Conflict And Work Stress On Organizational Commitments With Work Satisfaction As Intervening Variables. International Journal For Innovative Research In Multidisciplinary Field. Vol. 6, Issue 7, July - 2020: 10-17. Permono, Iswardono S dan Darmawan. 2010. "Analisis Efisiensi Industri Perbankan di Indonesia (Studi kasus Bank-Bank Devisa di Indonesia Tahun 1991-1996)". Jurnal Ekonomi dan Bisnis Indonesia. Universitas Gajah Mada. Yogyakarta.

Sitompul, S. 2018. Pengaruh ukuran perusahaan, kebijakan pendanaan, Risk based capital (RBC), pertumbuhan premi netto dan laba perusahaan terhadap nilai perusahaan pada perusahaan Asuransi yang terdaftar di Bursa Efek Indonesia. Universitas Sumatera Utara.

Sitompul, S. (2019). Pengaruh Motivasi Dan Kepemimpinan Terhadap Prestasi Kerja Pada PT. PLN (Persero) Unit Induk Pembangunan II Medan. Jurnal Ilmiah METADATA, 1(2), 93-105.

Sitompul, Saleh dan Nasution, Siti Khadijah. 2019. The Effect of Car, BOPO, NPF, and FDR on Profitability of Sharia Commercial Banks in Indonesia. E-ISSN: 2615-3076. Budapest International Research and Critics Institute (BIRCI-Journal) : Humanities and Social Sciences. Vol. 2. No. 3.

Sitompul, Saleh dan Siti Khadijah. 2020. Analysis Net Profit, Dividend, Debt, Cash Flow, and Capital Net Working That Influence Investment Decisions on Manufacturing Companies. International Journal of Research and Review. Vol.7; Issue: 3; March 2020.

Sutawijaya, Adrian dan Etty Puji Lestari. 2019. "Efisiensi Teknik Perbankan Indonesia Pasca krisis Ekonomi :Sebuah Studi Empiris Penerapan Model DEA". Jurnal Ekonomi Pembangunan, Vol. 10, No. 1, Juni 2019. 